\title{
KERAGAAN KEMITRAAN DI KOPERASI PRODUKSI SUSU (STUDI KASUS DI KPS BOGOR, KEDUNG BADAK, KOTA BOGOR)
}

\author{
${ }^{1}$ Annisa Indah Kartika, ${ }^{2}$ Sara Ratna Qanti \\ 1,2 Departemen Sosial Ekonomi, Fakultas Pertanian, Universitas Padjadjaran \\ Email: *sara.ratna.qanti@unpad.ac.id
}

\begin{abstract}
ABSTRAK
Peningkatan produksi susu di Indonesia masih belum mencukupi kebutuhan konsumsi susu di Indonesia yang juga terus meningkat. Koperasi Produksi Susu (KPS) hadir untuk memfasilitasi para peternak sapi perah. KPS tidak dapat menjalankan seluruh kegiatannya sendiri maka KPS menjalin kerja sama dalam memenuhi sarana produksi, distribusi, kualitas, dan kontinuitas. Tujuan penelitian ini adalah untuk mengetahui pola dan keragaan kemitraan yang terjadi pada KPS Bogor. Penelitian dilakukan di KPS Bogor di Jln. Baru Kedung Badak, Kelurahan Kedung Badak, Kecamatan Tanah Sareal, Kota Bogor, Jawa Barat. Penelitian dilakukan dengan desain deskriptif kualitatif dan teknik penelitian studi kasus. Responden dan informan ditentukan dengan sengaja. Data yang digunakan adalah data primer dan sekunder. Hasil penelitian menunjukkan bahwa KPS Bogor memiliki enam perusahaan mitra yaitu PT. AMS, CV. MAJU, Cimory, Indolakto, Nutrifood, dan Unican. Hanya satu dari enam perusahaan ini yang memiliki perjanjian tertulis yaitu PT. AMS dalam bentuk Kerja Sama Operasi (KSO). Perjanjian tidak tertulis dengan Indolakto, Cimory, Nutrifood, dan Unican dalam bentuk kemitraan subkontrak, dan CV. MAJU dalam bentuk vertical forward linkage. Dalam pelaksanaan kerjasama antara KPS dan mitra, banyak proses yang dilakukan secara spontan.
\end{abstract}

Kata kunci: susu, keragaan, kemitraan, kerja sama bisnis, spontan

\begin{abstract}
Milk production in Indonesia is still insufficient to fulfil increasing milk consumption in Indonesia. West Java is one of the largest milk production centre in Indonesia and also place where there are many milk production cooperatives (MPC). MPC presents to facilitates the dairy farmers. MPC was not able to run the entire business itself, then it cooperates with various partners in term of production facilities, distribution, quality control, and continuity. The purpose of this study is to determine the pattern and the performance of partnerships at the MPC in Bogor. The study was conducted at the MPC in Bogor located at Jln. Baru Kedung Badak, Kedung Badak Village, Tanah Sareal District, City of Bogor, West Java. Descriptive design and a qualitative case study research technique were used in this study. Primary data were collected by using participant observation and interviews. Both primary and secondary data were used in this study. Important results suggest that $M P C$ in Bogor has six partner companies, namely PT. AMS, CV. MAJU, Indolakto, Cimory, Nutrifood, and Unican. Only one (PT. AMS) of these six companies has written agreement and in form of Joint Operation. The unwritten agreements with Indolakto, Cimory, Nutrifood, and Unican are in subcontract partnerships form, and CV. MAJU is in vertical forward linkage form. In the implementation of partnerships, many processes are carried out spontaneously.
\end{abstract}

Keywords: milk, the performance, partnerships, business collaboration, spontaneous

\section{PENDAHULUAN}

Kebutuhan protein hewani masyarakat Indonesia terus meningkat. Hal ini turut meningkatkan grafik konsumsi susu di Indonesia. Berbeda dengan permintaannya, produksi susu dalam rangka pemenuhan kebutuhan konsumsi susu masih belum optimal. Koperasi hadir sebagai salah satu alternatif wadah atau lembaga yang diharapkan mampu membantu memenuhi kebutuhan tersebut. Dengan adanya koperasi, para peternak sapi perah dapat saling bertukar informasi dan saling membantu dalam meningkatkan produktifitas dan kesejahteraan bersama-sama berasaskan semangat kekeluargaan.

Koperasi Produksi Susu (KPS) Bogor sebagai koperasi primer, dinilai cukup baik 
dalam menjalankan fungsi perkoperasiannya. Hal ini dapat dilihat dari fakta-fakta bahwa KPS Bogor sudah memenuhi hal-hal yang dinilai penting dalam aktivitas agribisnis susu. Di antaranya adalah sarana produksi, kontinuitas, kualitas, dan pasar atau pendistribusian. KPS Bogor dalam memenuhi hal-hal tersebut tidak bisa menjalankan sepenuhnya sendirian. Salah satu alternatif jalan keluar yang digunakan oleh KPS Bogor dalam memenuhi hal-hal tersebut adalah melalui kemitraan.

KPS Bogor dalam sehari memiliki kapasitas produksi sebesar 5.000-6.000 liter di Kedungbadak dan 9.000-12.000 liter di Leuwiliang. Dalam memasarkan produk susu segar dari para anggotanya, KPS Bogor bekerja sama dengan beberapa IPS yaitu Indolakto dan Cimory. Selain itu KPS Bogor juga melakukan diferensiasi produk dan tidak hanya bertindak sebagai penampung melain-kan sebagai pengolah juga. Hal ini diwujudkan dengan bermitra dengan CV. Mitra Agro Jaya Utama (CV. MAJU) yang mengolah susu segar menjadi susu pasteurisasi, yogurt, dan puding susu. Tulisan ini bertujuan untuk memetakan pola dan keragaan kemitraan yang terjadi pada KPS Bogor.

\section{METODE PENELITIAN}

Objek dalam penelitian ini adalah pola dan keragaan kemitraan yang terdapat di KPS Bogor, Kedungbadak, Kota Bogor. Pemilihan tempat dilakukan atas dasar pertimbangan bahwa KPS Bogor merupakan salah satu koperasi susu yang berhasil dilihat dari segi pemenuhan sarana produksi, kontinuitas, kualitas, dan pasar atau pendistribusian. Selain itu KPS Bogor juga mengelola sebuah klaster usaha peternakan sapi perah yang berada di Leuwiliang, Kabupaten Bogor.

Desain yang digunakan dalam penelitian ini adalah kualitatif. Penelitian kualitatif adalah prosedur penelitian yang menghasilkan data deskriptif berupa kata-kata tertulis atau lisan dari orang-orang dan perilaku yang dapat diamati (Bogdan dan Tylor, 1990). metode penelitian yang dipilih adalah studi kasus. Data yang digunakan dalam penelitian ini terdiri dari data primer dan data sekunder. Informan dalam penelitian ini adalah orang-orang yang dianggap tahu dan terlibat dalam kemitraan di KPS Bogor. Di antaranya adalah 30 orang responden anggota, 1 orang manajer KPS Bogor, 3 orang karyawan KPS Bogor, 2 orang karyawan CV. MAJU, dan 2 orang karyawan PT. Andini Megah Sejahtera (PT. AMS).

\section{HASIL DAN PEMBAHASAN}

KPS Bogor menjalin kemitraan dengan berbagai perusahaan dan instansi juga. Hubungan kemitraan KPS Bogor dengan berbagai perusahaan dan instansi dapat dilihat pada Tabel 1. Kedudukan badan hukum KPS Bogor di Kabupaten Bogor dengan nomor badan hukum No.4654/A/BH/KWK.10/III/ 1996. Jumlah anggota KPS Bogor yang aktif mengirim susu adalah sebanyak 253 orang dengan 3.376 ekor sapi perah. KPS Bogor mampu mendapatkan susu mencapai 12.000 14.000 liter dalam satu hari. Selain kemitraan, KPS Bogor juga memiliki unit-unit usaha. Unit-unit usaha ini ada yang dikelola sendiri ataupun dikelola dengan bermitra.

Tabel 1. Hubungan Kerja Sama KPS Bogor

\begin{tabular}{|c|c|c|}
\hline Instansi & Agenda Kerja Sama & Tahun \\
\hline Indolakto & $\begin{array}{l}\text { KPS Bogor mengirimkan } \\
\text { susu murni segar. }\end{array}$ & $\begin{array}{l}1970- \\
\text { sekarang }\end{array}$ \\
\hline \multirow[t]{2}{*}{ BRI } & $\begin{array}{l}\text { Pemberian kredit lunak } \\
\text { untuk kepemilikan sapi } \\
\text { bagi anggota melalui } \\
\text { KPS Bogor. }\end{array}$ & $\begin{array}{l}1998- \\
2003\end{array}$ \\
\hline & $\begin{array}{l}\text { Pemberian kredit bagi } \\
\text { anggota secara langsung. }\end{array}$ & $\begin{array}{l}2003- \\
\text { sekarang }\end{array}$ \\
\hline Diamond & $\begin{array}{l}\text { KPS Bogor mengirimkan } \\
\text { susu murni segar. }\end{array}$ & $\begin{array}{l}2008- \\
2010 \\
\end{array}$ \\
\hline Unican & $\begin{array}{l}\text { KPS Bogor mengirimkan } \\
\text { susu murni segar. }\end{array}$ & $\begin{array}{l}2009 \text { - } \\
\text { sekarang }\end{array}$ \\
\hline PT. Telkom & $\begin{array}{l}\text { Pemberian kredit lunak } \\
\text { untuk kepemilikan sapi } \\
\text { bagi anggota melalui } \\
\text { KPS Bogor. }\end{array}$ & $\begin{array}{l}2010- \\
2015\end{array}$ \\
\hline Cimory & $\begin{array}{l}\text { KPS Bogor mengirimkan } \\
\text { susu murni segar. }\end{array}$ & $\begin{array}{l}2011- \\
\text { sekarang }\end{array}$ \\
\hline $\begin{array}{l}\text { Bank } \\
\text { Saudara }\end{array}$ & $\begin{array}{l}\text { Pemberian kredit bagi } \\
\text { anggota. }\end{array}$ & $\begin{array}{l}2012 \text { - } \\
\text { sekarang }\end{array}$ \\
\hline Nutrifood & $\begin{array}{l}\text { KPS Bogor mengirimkan } \\
\text { susu murni segar. }\end{array}$ & $\begin{array}{l}2014 \text { - } \\
\text { sekarang }\end{array}$ \\
\hline
\end{tabular}

Unit Pelayanan Susu Murni. Sebagian besar susu murni KPS Bogor dikirim ke industri pengolahan susu (IPS) yaitu PT. Cisarua Mountain Dairy (Cimory) dan PT. Indolakto. Ada juga yang diolah sendiri dan bekerja sama dengan CV. MAJU. Keadaan mutu susu (rataan kualitas) KPS Bogor mengandung Total Solid (TS) $=11,8 \%$, protein $=2,8 \%$ dan lemak $=3,8 \%$. Tempat penampungan susu (TPS) KPS Bogor menerima susu dari para anggotanya dua kali sehari yaitu pagi dan sore hari. Sebelum susu dimasukkan ke dalam cooling unit dan 
digabungkan dengan susu dari para anggota lain, setelah susu dari setiap anggota diambil sampelnya untuk diperiksa di laboratorium.

Setelah pengambilan sampel, susu dimasukkan ke dalam cooling unit dan digabungkan dengan susu dari anggota lain. Setelah terkumpul, susu dipindahkan ke dalam truk tangki untuk kemudian diantarkan ke IPS. Salah satu kendala yang dihadapi KPS Bogor dalam bermitra dan mencari mitra adalah ketersediaan susu. Terbatasnya ketersediaan susu yang dimiliki oleh KPS Bogor membuat KPS Bogor masih belum mampu secara konsisten memenuhi kebu-tuhan IPS-IPS yang sudah bermitra. Hal ini pula yang membuat KPS Bogor masih sulit untuk menjalin kemitraan dengan IPS-IPS baru lainnya.

Unit Usaha Pakan Ternak. Menurut keterangan para anggota, antara tahun 19902000 KPS Bogor mampu memproduksi pakan sendiri. Salah satu alasan berhentinya produksi pakan KPS Bogor adalah dikarenakan karyawan yang bertanggung jawab terhadap pembuatan pakan tidak bekerja lagi di KPS Bogor. Meskipun demikian, KPS Bogor berusaha untuk tetap menyediakan pakan produksi sendiri. Akhirnya KPS Bogor bermitra dengan sebuah perusahaan pembuat pakan yaitu PT. Andini Megah Sejahtera (PT. AMS) sejak tahun 2013. Hasil produksi pada tahun 2015 sebanyak 450 ton/bulan dan sudah sesuai dengan kebutuhan anggota. Untuk pakan sapi perah disediakan dua grade mutu pakan yaitu dengan kandungan protein kasar (PK) 13\%-15\% dan PK 16\%-18\%.

Unit Usaha Susu Olahan. KPS Bogor menjalankan unit usaha ini bekerja sama dengan CV. MAJU. Lokasi produksi sekaligus kantor dan kios CV MAJU berada di dalam lingkungan kantor KPS Bogor Selain dengan CV. MAJU, KPS Bogor juga memulai produksi susu pasteurisasi baru di kawasan KUNAK. Produksi susu pasteurisasi ini dilakukan dan dikelola sepenuhnya oleh KPS Bogor. Salah satu kendala yang dialami oleh KPS Bogor dalam kemitraannya dengan CV. MAJU adalah pembayaran yang kurang lancar. Ini dikarenakan belum banyaknya konsumen tetap, sehingga berimbas pada pendapatan yang belum stabil dan secara langsung mempenga-ruhi pembayaran CV. MAJU kepada KPS Bogor.

Unit Usaha Simpan Pinjam. Omzet per tahun yang didapatkan KPS Bogor berkisar antara Rp750.000.000-Rp1.000.000.000. Yang bisa melakukan kegiatan simpan pinjam pada unit ini di KPS Bogor adalah hanya yang sudah terdaftar menjadi anggota KPS Bogor selama minimal satu tahun. Anggota KPS Bogor setiap bulan melakukan simpanan wajib yang dipotong dari uang pembayaran susu sebesar Rp10,-/liter susu yang dibayarkan oleh KPS Bogor. Untuk peminjaman, anggota yang meminjam uang tidak perlu memberikan jaminan lain. Hal ini dikarenakan yang dijadikan jaminan adalah uang hasil pembayaran susu para anggota. Selain itu penentuan plafond peminjaman juga tergantung dari kemampuan anggota dalam memasok susu. Jangka waktu pengembalian biasanya satu bulan hingga lima tahun. Cicilan pengembalian dana dipotong langsung dari uang pembayaran susu anggota.

Warung Serba Ada (Waserda). Waserda difokuskan pada penyediaan obatanobatan, serta peralatan kandang (tali, arit, karpet sapi, sepatu kandang, asahan dan sebagainya). Keuntungan yang didapatkan oleh anggota (jika membeli produk di Waserda) adalah tidak membayar tunai. Pembayaran dapat dilakukan dengan pemotongan kas dari uang pembayaran susu pada bulan yang sama dengan saat dilakukan pembelanjaan di Waserda. Untuk penyediaan obat-obatan ternak, KPS Bogor bekerja sama dengan berbagai perusahaan farmasi. Bentuk kerja samanya adalah dengan penundaan pembayaran dari KPS Bogor ke perusahaan farmasi tersebut. Kerja sama ini dilakukan dengan fleksibel tanpa ada kesepakatan tertulis dan berjalan baik berdasarkan kepercayaan antara KPS dengan perusahaan-perusahaan farmasi tersebut.

Kunak. Kawasan Usaha Peternakan Sapi Perah (Kunak) Bogor berlokasi di Kecamatan Cibungbulang, Kabupaten Bogor. Kawasan ini dibangun sebagai kawasan yang memfokuskan diri pada usaha peternakan sapi perah. Kunak memiliki 181 kaveling dengan kandang sapi yang dapat menampung dua belas sapi perah dewasa di masing-masing kaveling. Untuk fasilitas umum yang tersedia di Kunak adalah cooling unit dan mesin chiller di TPS, mesin pasteurisasi, genset, gudang pakan, bangunan Waserda, kandang pembibitan, waduk dan tandon air, mushola, sekolah, dan lapangan olah raga. Mekanisme penerimaan susu di TPS Kunak relatif sama dengan di TPS KPS Bogor.

Hubungan KPS dengan Anggota. KPS Bogor saat ini memiliki total anggota sebanyak 1156 orang dengan 253 orang anggota yang 
masih aktif. Syarat untuk menjadi anggota KPS Bogor adalah memiliki usaha ternak sapi perah dengan jumlah sapi minimal dua ekor. Seorang anggota dikatakan aktif jika masih mengirimkan susu dan membayar simpanan wajib sebesar Rp10,-/liter yang dipotong dari uang pembayaran susu anggota.

Kebanyakan anggota KPS Bogor membagi susu hasil perahan untuk dijual ke beberapa tempat. Meskipun begitu, para anggota ini tetap bertahan mengirim susu ke KPS Bogor. Hal ini dikarenakan adanya kepastian pembayaran yang didapatkan dari KPS Bogor, fleksibilitas penerimaan susu oleh pihak KPS Bogor bahkan saat bulan Ramadhan dan hari raya keagamaan, dan ketersediaan dana segar minim syarat di KPS Bogor yang memudahkan anggota melakukan kas bon juga membuat anggota masih bertahan. Selain kas bon, anggota dapat meminjam dana di unit usaha simpan pinjam.

Pembayaran yang dilakukan KPS Bogor kepada anggotanya dilakukan tunai setiap tanggal 1 setiap bulannya dan dilakukan di kantor KPS Bogor di Kota Bogor. Hal-hal yang menjadi perhatian KPS Bogor saat memberikan harga beli kepada para anggotanya adalah kuantitas, kualitas, serta kandungan protein dan lemak dalam susu yang dikirim oleh mereka. Harga beli dari KPS Bogor biasanya mulai dari Rp4.100,- hingga Rp4.995,- per liter. Salah satu faktor yang sangat mempengaruhi kualitas dan kandungan susu yang dihasilkan adalah pakan. Para anggota dapat membeli pakan keluaran KPS Bogor dan PT. AMS dengan merek CaLFEED langsung di kantor KPS Bogor.

Kemitraan dengan PT. AMS. Lokasi kantor PT. AMS di Bogor berada di lingkungan kantor KPS Bogor. Awal mula KPS Bogor bermitra dengan PT. AMS adalah ketika KPS Bogor sudah tidak mampu lagi menjalankan unit usaha pembuatan pakan sendiri. PT. AMS dengan KPS Bogor bermitra dalam membuat pakan ternak berlabel merek CaLFEED. Pada diversifikasi produknya, CaLFEED memiliki empat jenis varian yaitu CaLFEED P-132, CaLFEED H-132, CaLFEED H-133, CaLFEED P-122.

Model kemitraan yang terjalin antara PT. AMS dengan KPS Bogor disebut Kerja Sama Operasi (KSO). KSO ini merupakan perjanjian tertulis yang disepakati oleh kedua belah pihak pada tanggal 15 April 2013. Masa berlaku KSO antara PT. AMS dan KPS Bogor adalah tiga tahun.

Kesepakatan-kesepakatan pada perjanjian tersebut adalah terutama mengenai pemisahan dan hak guna sumber daya. PT. AMS memiliki dan bertanggung jawab atas SDM dan tenaga kerja, manajemen unit usaha, serta bahan baku pembuatan pakan. Untuk tempat pembuatan pakan, lokasi kantor, gudang pakan, dan mesin pembuatan pakan merupakan milik KPS Bogor. Dalam realisasinya, meskipun berdasarkan perjanjian tertulis, KSO tetap didasari asas kekeluargaan sehingga jika ada suatu hal yang menyimpang dari kebutuhan dan tujuan kedua pihak akan dimusyawarahkan dan diselesaikan bersama. PT. AMS memiliki hak penuh atas penggunaan aset milik KPS Bogor pada unit usaha pembuatan pakan. Untuk kewajiban PT. AMS terhadap KPS Bogor adalah pemenuhan kebutuhan pakan para anggota KPS Bogor dan pemberian kompensasi pada KPS yang terbagi dua macam yaitu fee produksi dan fee market.

\section{Fee Produksi}

$\begin{aligned} \text { Fee produksi } & =\mathrm{Rp} 50,-/ \mathrm{kg} \\ \text { Kapasitas produksi per hari } & =15 \text { ton } \\ & =15.000 \mathrm{~kg} \\ \text { Satu bulan } & =30 \text { hari } \\ \text { Fee produksi satu bulan } & =30(\mathrm{Rp} 50 \times 15.000 \mathrm{~kg}) \\ & =30\left(\mathrm{Rp} 750.000,^{-}\right) \\ & =\mathrm{Rp} 22.500 .000,^{-} / \mathrm{bulan}\end{aligned}$

Fee Market

$\begin{array}{ll}\text { Fee market } & =\mathrm{Rp} 25 / \mathrm{kg} \\ \text { Rata-rata kuantitas pakan } & \\ \text { terserap anggota KPS Bogor } & =150 \text { ton } / \mathrm{bulan} \\ & =150.000 \mathrm{~kg} \\ \text { Fee market } \text { satu bulan } & =\mathrm{Rp} 25 \times 150.000 \\ & =\mathrm{Rp} 3.750 .000,-/ \mathrm{bulan}\end{array}$

Pembelian pakan oleh anggota dibayar melalui pemotongan dari uang pembayaran susu mereka setiap bulan. Ini merupakan salah satu keuntungan anggota sehingga tidak perlu membeli dan membayar tunai. Ketersediaan pakan di KPS Bogor selalu ada. PT. AMS mampu memproduksi pakan hingga 15 ton dari dua buah mesin setiap harinya.

Kemitraan dengan CV. MAJU. CV. MAJU merupakan salah satu pembeli utama susu dari KPS Bogor dengan lokasi produksi dan kios yang berada di dalam lingkungan KPS Bogor. CV. MAJU merupa-kan mitra KPS Bogor dalam pembuatan pro-duk olahan dari susu sapi segar. Beberapa pro-duk yang diproduksi adalah susu pasteurisasi dan yogurt dalam berbagai ukuran kemasan.

Dalam hubungannya saat ini CV. MAJU 
tidak memiliki kontrak atau perjanjian tertulis dengan KPS Bogor, begitupun dengan tuntutan-tuntutan tertentu. Untuk masa berlaku kontrak antara KPS Bogor dan CV. MAJU adalah lima tahun dimulai dari 2011. Hubungan yang terjalin antara CV. MAJU dan KPS Bogor saat ini bersifat kekeluargaan dan berdasarkan asas kepercayaan.

Untuk hak dan kewajiban antara CV. MAJU dan KPS Bogor saat ini hanya terkait mengenai penggunaan bangunan. CV. MAJU berhak menempati salah satu kaveling di dalam lingkungan kantor KPS Bogor sebagai lokasi produksi dan kios dan berhak menggunakan alatalat produksi susu pasteurisasi milik KPS Bogor. Untuk kewajiban CV. MAJU terhadap KPS Bogor yaitu membayar uang sewa kaveling, kompensasi penggunaan alat dan mesin pasteurisasi, serta listrik setiap bulan sebesar Rp4.500.000,-. Pembayaran susu segar yang dibeli CV. MAJU untuk diolah kembali dilakukan kepada KPS Bogor setiap bulan dengan nilai kumulatif berdasarkan banyaknya susu segar yang diambil oleh CV. MAJU.

Kemitraan dengan Indolakto. KPS Bogor memiliki mitra pada hilir yaitu industri pengolahan susu (IPS) besar yang meminta pasokan susu segar dalam jumlah besar setiap harinya. Salah satu IPS yang bekerja sama dengan KPS Bogor adalah PT. Indolakto. Indolakto merupakan IPS yang rutin dan kontinu meminta dan memesan susu segar dari KPS Bogor setiap hari. Permintaan ini adalah untuk pabrik Indolakto yang berada di Jakarta. Kapasitas produksi pabrik Indo-lakto dalam satu hari adalah mencapai 257 ton.

Dalam pelaksanaan kemitraan, KPS Bogor dan Indolakto tidak memiliki perjanjian tertulis dan dilakukan secara lisan. Dengan bentuk kerja sama seperti ini terlihat bahwa hubungan antara KPS Bogor dan Indolakto terjalin berdasarkan kekeluargaan dan kepercayaan. Hubungan baik ini terjalin karena KPS Bogor dan Indolakto sudah menjalin kerja sama dalam waktu yang lama yaitu sejak KPS Bogor pertama kali berdiri atau selama hampir 45 tahun.

Indolakto biasanya memberikan harga sebesar Rp4.900,-/liter kepada KPS Bogor. Penentuan harga ini tidak dilakukan secara tertulis dan dapat berubah sewaktu-waktu. Selain itu, Indolakto akan memberikan bonus dan tambahan pembayaran apabila susu segar yang dikirim KPS Bogor memiliki kandungan total solid (TS) yang tinggi. Kandungan TS yang ditentukan oleh Indolakto adalah $\geq 11,5$.

Permintaan susu segar dari Indolakto terhadap KPS Bogor adalah 9.000 liter/hari. Tetapi pada kenyataannya, Indolakto sangat kompromis mengenai kuantitas sehingga meskipun pasokan dari KPS Bogor tidak memenuhi permintaan dan pesanan, Indolakto tetap menerima pasokan tersebut. Bahkan jika KPS Bogor mengirimkan susu melebihi jumlah permintaan, Indolakto akan tetap menerima kiriman susu tersebut.

KPS Bogor selalu memiliki ketersediaan susu segar berapapun kuantitasnya. Biasanya KPS Bogor selalu memiliki ketersediaan minimal 6.000 liter di TPS KUNAK setiap hari. Susu segar yang dikirim ke Indolakto adalah susu yang sudah melewati tahapan di unit pelayanan susu murni atau TPS.

Kemitraan dengan Cimory. Selain dengan Indolakto, KPS Bogor juga memiliki mitra lain yaitu PT. Cimory. Cimory merupakan perusahaan susu yang memproduksi berbagai macam produk turunan susu. Salah satu produk terkenal dari Cimory adalah yogurt. Cimory juga merupakan IPS yang rutin dan kontinu meminta dan memesan susu segar dari KPS Bogor setiap hari. Permintaan ini adalah untuk pabrik Cimory yang berada di Sentul. Kapasitas produksi pabrik Cimory Sentul dalam satu hari adalah mencapai 800 ton. Kiriman susu dari KPS Bogor adalah \pm 3 ton setiap hari.

Pelaksanaan kemitraan KPS Bogor dan Cimory tidak memiliki perjanjian tertulis. Pemesanan dan berbagai macam kesepakatan dilakukan secara lisan sehingga dapat terlihat bahwa hubungan antara KPS Bogor dan Cimory terjalin berdasarkan kekeluargaan dan kepercayaan. Hubungan baik ini terjalin selain karena KPS Bogor sudah memiliki reputasi yang cukup baik, juga dikarenakan KPS Bogor mampu menjaga kepercayaan yang diberikan oleh Cimory.

Cimory biasanya memberikan harga sebesar Rp5.300,-/liter kepada KPS Bogor. Nilai ini sedikit lebih tinggi jika dibandingkan dengan harga yang diberikan oleh Indolakto. Penentuan harga ini tidak dilakukan secara tertulis dan dapat berubah sewaktu-waktu sesuai dengan aturan yang berlaku di Cimory, kondisi pasar, dan kandungan nutrisi pada susu dari KPS Bogor. Selain itu, Cimory akan memberikan bonus dan tambahan pembayaran apabila susu segar yang dikirim KPS Bogor memiliki kandungan nutrisi seperti protein 
yang tinggi. Kandungan TS yang ditentukan oleh Cimory adalah $\geq 11$.

Permintaan susu segar dari Cimory terhadap KPS Bogor adalah 25.000 liter/minggu atau sekitar 3.600 liter/hari. Tetapi Cimory juga sangat kompromis mengenai kuantitas sehingga meskipun pasokan dari KPS Bogor tidak memenuhi permintaan dan pesanan, Cimory tetap menerima pasokan tersebut. Tetapi KPS Bogor hampir selalu dapat memenuhi permintaan susu dari Cimory. Jika pun kurang secara kuantitas, biasanya tidak akan terlalu jauh di bawah 3.000 liter.

KPS Bogor selalu memiliki ketersediaan susu segar di TPS. Biasanya KPS Bogor selalu memiliki ketersediaan minimal 3.000 liter di TPS KPS Bogor setiap hari. Sama halnya dengan susu segar yang dikirim ke Indolakto, susu segar yang dikirim ke Cimory adalah susu yang sudah melewati tahapan di unit pelayanan susu murni atau TPS.

\section{Kemitraan dengan Nutrifood dan}

Unican. Selain dengan Indolakto dan Cimory sebagai IPS mitra dengan permintaan dan kiriman rutin, KPS Bogor juga memiliki mitra lain yang juga IPS yaitu Nutrifood dan Unican. Perbedaan antara Nutrifood dan Unican dengan Indolakto dan Cimory adalah frekuensi permintaan dan pemesanan susu segar. Jika Indolakto dan Cimory rutin meminta dan memesan susu segar setiap hari kepada KPS Bogor, Nutrifood dan Unican tidak rutin meminta dan memesan susu segar dari KPS Bogor.

Nutrifood dan Unican hanya melakukan permintaan dan pemesanan jika kebutuhan mereka sedang meningkat. Frekuensi pemesanannya sangat tidak tentu. Oleh Nutrifood, susu segar dari KPS Bogor diolah menjadi minuman yogurt dengan merek Heavenly Blush sedangkan Unican mengolahnya menjadi permen dengan merek Milkita. Lokasi pabrik Nutrifood adalah di Sentul sedangkan Unican terletak di Serang, Banten. Untuk Nutrifood, kiriman susu dilakukan dari TPS KPS Bogor sedangkan untuk Unican kiriman susu dilakukan dari TPS KUNAK. Hal ini dikarenakan perbedaan jumlah permintaan dari Nutrifood dan Unican.

Sama seperti Indolakto dan Cimory, KPS Bogor dengan Nutrifood dan Unican juga tidak memiliki perjanjian tertulis. Dengan bentuk kerja sama seperti ini terlihat bahwa hubungan antara KPS Bogor dengan Nutrifood dan Unican terjalin karena saling membutuhkan. Hubungan kemitraan antara KPS Bogor dengan Nutrifood dimulai pada tahun 2014, sedangkan untuk Unican dimulai sejak tahun 2009.

Untuk harga, Nutrifood memberikan harga sebesar Rp4.900/liter sedangkan Unican memberikan harga sebesar Rp5.800/liter. Harga yang diberikan dapat berubah sewaktuwaktu tergantung pada aturan yang berlaku di masing-masing perusahaan dan kondisi pasar. Dalam melakukan permintaan dan pemesanan, biasanya Nutrifood meminta sebanyak 5.000 liter dan Unican sebanyak 9.000 liter. Sama halnya dengan susu segar yang dikirim ke Indolakto dan Cimory, susu segar yang dikirim ke Nutrifood dan Unican adalah susu yang sudah melewati tahapan di unit pelayanan susu murni atau TPS.

\section{KESIMPULAN}

KPS Bogor memiliki enam perusahaan yang menjadi mitra yaitu PT. AMS, CV. MAJU, Indolakto, Cimory, Nutrifood, dan Unican. Dari keenam perusahaan ini, hanya satu yang memiliki perjanjian tertulis yaitu PT. AMS dalam bentuk Kerja Sama Operasi (KSO). Kelima perusahaan lainnya menjalin hubungan kemitraan dengan KPS Bogor tanpa perjanjian tertulis. Perjanjian tidak tertulis dengan Indolakto, Cimory, Nutrifood, dan Unican dalam bentuk kemitraan subkontrak, dan CV. MAJU dalam bentuk vertical forward linkage. Hubungan ini tumbuh berdasarkan kekeluargaan dan kepercayaan yang muncul dikarenakan sudah menjalin kerja sama untuk waktu yang lama seperti dengan Indolakto yang sudah 45 tahun dan Cimory yang sudah berjalan empat tahun. Dalam pelaksanaan kerjasama antara KPS dan mitra, banyak proses yang dilakukan secara spontan. Mulai dari penentuan harga hingga penyelesaian masalah yang dilakukan dengan musyawarah dan diselesaikan bersama-sama.

Beberapa keuntungan yang didapatkan anggota antara lain mendapatkan pakan dengan cara pembayaran yang mudah, KPS Bogor yang buka setiap hari selalu menerima susu berapapun kuantitas susu yang dikirimkan anggota, dan memiliki tujuan distribusi yang jelas. Untuk kerugian bagi anggota adalah harga yang didapatkan dari KPS Bogor lebih rendah jika dibandingkan menjual langsung kepada pembeli yang datang ke rumah anggota.

KPS Bogor dengan IPS-IPS yang sudah menjalin kerja sama dengan perjanjian lisan dapat lebih menegaskan dan melegalkan hubungan kerja sama yang terjalin dengan membuat perjanjian tertulis. Hal ini dilakukan 
untuk menghindari kerugian apabila terjadi hal-hal yang tidak diinginkan.

Selain itu KPS Bogor juga harus lebih aktif memberikan motivasi dalam berbagai cara dan bentuk kepada anggota agar mereka lebih produktif. Salah satu bentuk motivasi yang dapat diberikan adalah dengan lebih sering memberikan penyuluhan dan menguatkan tali kekeluargaan dan keakraban antara pengurus dan anggota. Salah satu yang dapat dilakukan adalah mengadakan pertemuan rutin di luar Rapat Anggota Tahunan.

\section{DAFTAR PUSTAKA}

Achmad, Firman. 2007. Kajian Koperasi Persusuan di Jawa Barat. Jatinangor: Universitas Padjadjaran.

Anonim. 2014. Rahasia Sukses Ternak Sapi Perah. Dalam http://disnak.kalselprov. go.id/2014/08/08/ternak-sapi-perah.html (diakses pada 27 Mei 2015, 18:44)

Gideon, Arthur. 2014. 80\% Kebutuhan Susu Nasional masih Impor. Dalam http://bisnis.liputan6.com/read/2058443/8 0-kebutuhan-susu-nasional-masih-impor (diakses pada 26 Oktober 2014, 17:08)

Kementerian Riset dan Teknologi. 2000. Budidaya Ternak Sapi Perah. Jakarta: Menristek.

Maryam. 2011. Pola Kemitraan Koperasi dengan Petani Karet Rakyat. Jatinangor: Unpad.

Maulana, Adi Ginanjar. 2014. Harga Susu Dunia Merosot, Peternak Lokal Kelimpungan. Dalam http://industri. bisnis.com/read/ 20140916/99/257686/harga-susu-duniamerosot-peternak-lokal-kelimpungan (diakses pada 30 Oktober 2014, 18:44)

Notoatmodjo, S. 2002. Metodologi Penelitian Kesehatan. Yogyakarta: Rineka Cipta.
Noviardi, Adhitya. 2012. Cimory Group Tingkatkan Kapasitas Produksi 8 Kali Lipat. Dalam http://industri. bisnis. com/ $\mathrm{read} / 20120425 / 257 / 74111 /$ cimory-grouptigkatkan-kapasitas-produksi-8-kali-lipat (diakses pada 28 Mei 2015, 19:48)

Prasetyo, Nurfahmi Budi. 2012. Indolakto Topping Off Pabrik di Pasuruan. Dalam http://industri.kontan.co.id/news/indolakto -topping-off-pabrik-di-pasuruan (diakses pada 28 Mei 2015, 19:34)

Prawirokusumo, Soeharto. 2001. Ekonomi Rakyat: Konsep, Kebijakan, dan Strategi. Yogyakarta: BPFE.

Ridwan, Muhammad. 2014. Rekonstruksi Model Kemitraan Contract Farming untuk Pengembangan Agribisnis Ayam Pedaging (Broiler) di Sulawesi Selatan. Makassar: Universitas Hasanuddin.

Sihombing, Martin. 2014. HARGA BELI SUSU: Rp4.000/Liter Belum Untungkan Peternak. Dalam http://industri.bisnis. com/read/20140524/99/230546/hargabeli-susu-rp4.000liter-belum-untungkanpeternak-untung (diakses pada 30 Oktober 2014, 19:10)

Saputro, Eko. 2014. Susu dan Kandungan Gizinya. Dalam http://bbppbatu.

bppsdmp.deptan. go.id/index.php?option=com_content\&vie $\mathrm{w}=$ article\&id=376:susu-dan-kandungangizinya\&catid $=72$ :artikel-peternakan (diakses pada 25 Januari 2015, 11:18)

Sutisna, Nanang. 2014. 134 Ribu Koperasi Alami Mati Suri dan Bangkrut. Dalam http://www.tempo.co/read/news/2014/12/ 21/058629968/134-ribu-koperasi-alamimati-suri-dan-bangkrut (diakses pada 28 Januari 2015, 12:35. 